\title{
The Assessment of Percutaneous Coronary Angioplasty versus Coronary Artery Bypass Grafting in Treatment of Left Main Coronary Artery Disease
}

\author{
SILVIU PAUL TRASCA ${ }^{1}$, CRISTINA FLORESCU1, VENERA CRISTINA DINESCU², ILEANA PUIU3, SORIN NICOLAE DINESCU4*, \\ DIANA RODICA TUDORASCU5, ELENA CATALINA BICA ${ }^{3}$, RAMONA CONSTANTINA VASILE ${ }^{4}$, FLORIN MARIUS ROMANESCU, \\ MARIUS GABRIEL BUNESCU ${ }^{2}$, NICOLETA CIOATERA ${ }^{7}$, EMILIA VIOLETA GOANTA ${ }^{1}$ \\ University of Medicine and Pharmacy of Craiova, Cardiology Department, 2 Petru Rares Str., 200349 Craiova, Romania \\ 2University of Medicine and Pharmacy of Craiova, Health Promotion and Occupational Medicine Department, 2 Petru Rares Str., \\ 200349 Craiova, Romania \\ ${ }^{3}$ University of Medicine and Pharmacy of Craiova, Pediatrics Department, 2 Petru Rares Str., 200349 Craiova, Romania \\ ${ }^{4}$ University of Medicine and Pharmacy of Craiova, Epidemiology and Primary Health Care Department, 2 Petru Rares Str., 200349 \\ Craiova, Romania \\ EUniversity of Medicine and Pharmacy of Craiova, Internal Medicine Department, 2 Petru Rares Str., 200349 Craiova, Romania \\ University of Medicine and Pharmacy of Craiova, Department of Physiology, 2 Petru Rares Str., 200349, Craiova, Romania \\ JUniversity of Craiova, Chemistry Department, 107i Calea Bucuresti Str., Craiova, Romania
}

\begin{abstract}
The aim of our study was to assess the percutaneous coronary angioplasty versus coronary artery bypass grafting in the treatment of the left main coronary artery disease. The study was a prospective, analytical, observational descriptive one, it included a total number of 83 patients, consecutively included in order to avoid bias, for a period of three years between October 2012 and December 2015. The follow-up was performed for 3 years, initially at one month, then at an interval of three to six months. The primary clinical endpoint was mortality of any cause of the patients included in the study. Other main objectives assessed in our study were symptomatic ischemic heart disease manifested with angina pectoris, the need for myocardial revascularization, nonfatal myocardial infarction, and reduction of left ventricular ejection fraction. In patients with $L M C A D$, we noticed an increase in mortality in patients with $P C l$ vs. $C A B G$, recurrence of angina pectoris, acute myocardial infarction, myocardial revascularization, and depression of the ejection fraction of the left ventricle. In conclusion, the treatment of left main coronary artery disease by using coronary artery bypass grafting is superior to treatment using percutaneous coronary angioplasty.
\end{abstract}

Keywords: left main coronary artery disease, coronary artery bypass grafting, percutaneous coronary angioplasty

In the past decades percutaneous coronary intervention ( $\mathrm{PCl})$ has been used as an alternative to coronary artery bypass grafting ( $C A B G)$ in patients with left main coronary artery disease $[1,2]$. Despite the increase in $\mathrm{PCl}, \mathrm{CABG}$ has shown superiority in patients with left main coronary artery disease [1-3].

The incidence of left main coronary artery disease (LMCAD) among patients who are explored by coronary angiography is approximately $6 \%$, with a range of $4-9 \%$ [3, 4].

Although not very common, according to the incidence described above, LMCAD continues to remain a problem between interventional cardiologists and cardiac surgeons in treating this type of disease [3]. This topic began in 1975, when Gorlin and Cohen were the first to compare LMCAD's surgical treatment with other therapeutic alternatives, highlighting the superiority of CABG over drug therapies [5].

It should be noted that the introduction of revascularization of $L M C A D$ via bare-metal stents (BMS) is providing an alternative to the surgical treatment, but the degree of restenosis stent remained increased, resulting an increased risk of major adverse cardiac events [1, 3] . Since the introduction of drug-eluting stents (DES), the risk of restenosis was lower, so this type of stent was taken into account in clinical trials that compared percutaneous coronary intervention vs. surgical revascularization in patients with LMCAD [6].

\section{Experimental part}

The aim of the study

The present study proposed fully and detailed comparison between treatment via percutaneous coronary angioplasty versus coronary artery bypass grafting in patients with left main coronary artery disease.

\section{Material and methods}

The study was a prospective, analytical, observational descriptive one, a total number of 83 patients were consecutively included in the study in order to avoid bias, during a period of three years from October 2012 to December 2015.

Each patient included in our study has signed both the informed consent and the acceptance consent. The study was approved by the Ethics Committee of the University of Medicine and Pharmacy Craiova and was conducted in accordance with international forums for medical studies, noting here Declaration of Helsinki issued by the Medical Association International (WMA - World Medical Association), Good Clinical Practice and all relevant regulations.

Each patient was also discussed in the Heart Team, which included at least one interventional cardiologist physician and at least one cardiac surgeon and the most appropriate therapeutic decision according to the clinicalpathological characteristics of each patient was taken. Generally, patients who were treated with $\mathrm{PCl}$ were those

* email: dinescus73@yahoo.com; Phone: +40745632232 
who refused surgical treatment, who had an increased surgical risk or who had limited life expectancy.

The inclusion criteria for patients in our study were: acute myocardial infarction without ST segment elevation, unstable or stable angina pectoris, patients with LMCAD defined as $350 \%$ of the left main coronary artery stenosis at coronary angiography. The exclusion criteria in our study were: patient refusal to myocardial revascularization, life expectancy below one year, increased surgical risk determined by Euroscore of at least 8 or greater, acute myocardial infarction with ST elevation segment in the first $24 \mathrm{~h}$ after onset, or patients who had absolute contraindications to dual antiplatelet therapy.

$\mathrm{PCl}$ was performed using the Selginger tehcinique. In most cases, the approach was transfemoral and only in a few cases the approach was transradial, due to peripheral vascular disease. The coronarographic evaluation revealed both single left main stenosis and LMCAD combined with one-, two-, three-vessels disease (fig. 1-3), so the purpose of the treatment was the complete revascularization of all vessels with significant lesions.

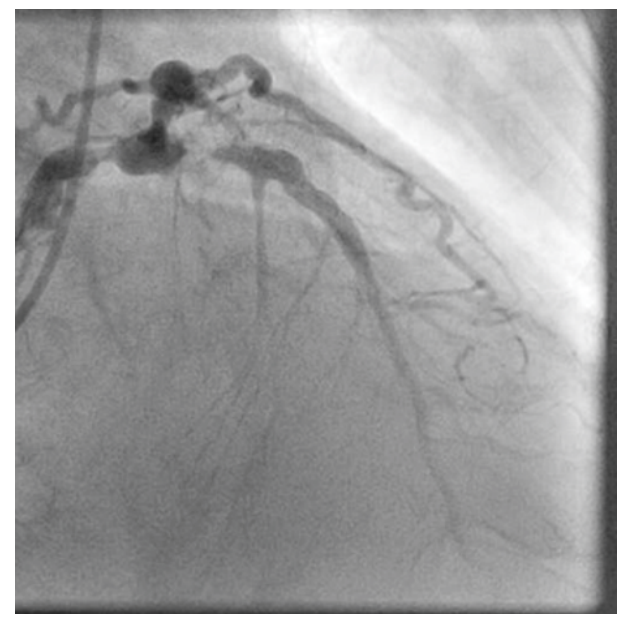

Fig. 1. Midshaft left main stenosis - RAO-Cranial view.

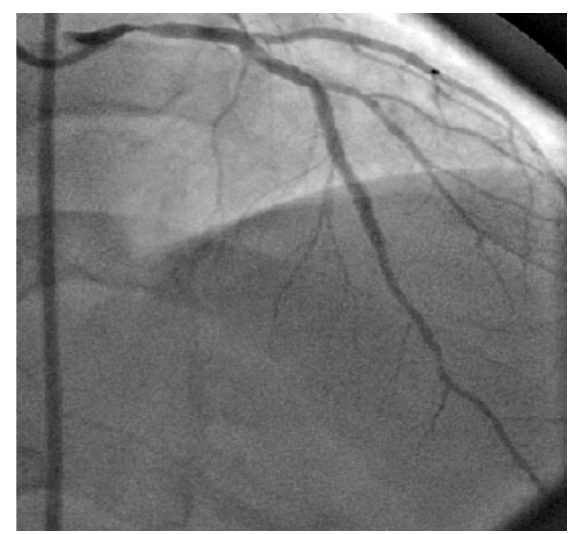

Fig. 2. Ostial left main disease - RAO-Cranial view.

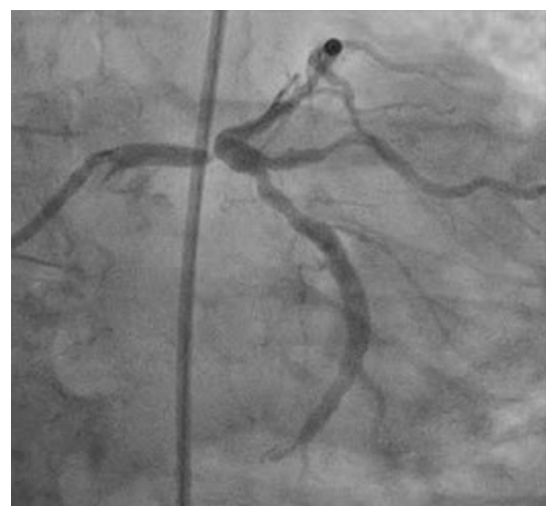

Fig. 3. Distal left main disease - AP-Caudal view.
In terms of interventional treatment, a single stent was used for proximal (ostium) or mid-shaft lesions. In the case of distal lesions, there were many therapeutic options, usually used was the technique of using two stents. Also, depending on the $\mathrm{PCl}$ operator's experience and on the morphology of the lesion, T-stenting, V-stenting, mini crush or single-stent strategy could be used for distal lesions. To finish the distal left main stenting procedure, post-dilation with kissing balloon angioplasty was used.

In the case of surgical treatment, the current recommendations in clinical practice have been used. In most cases, left internal mammary artery grafts for revascularization of the left anterior descending coronary artery, and rarely radial artery grafts, saphenous venous grafts of the right internal mammary artery, have been used.

The follow-up was performed for three years, initially at one month, then at an interval of three to six months.

The primary clinical endpoint was mortality of any cause of the patients included in the study. Other main objectives assessed in our study were symptomatic ischemic heart disease manifested with angina pectoris, the need for myocardial revascularization, nonfatal myocardial infarction, and reduction of left ventricular ejection fraction.

All statistical tests were performed with GraphPad Software (version 6, GraphPad Software, La olla, CA, USA). All results were reported as mean and standard deviation. In order to compare the average of the two groups, we used the t-student test, while to compare the averages of more than two groups, we used the analysis of the ANOVA variant. For the timely evaluation of primary and secondary endpoints in patients with LMCAD treated either by $\mathrm{PCl}$ or CABG, we used the Kaplan-Meier curves with the Logrank (Mantel-Cox) test. In all cases, the statistically significant difference was recorded if the value of $P$ was less than 0.05 .

\section{Results and discussions}

Concerning the all-cause mortality of patients suffering from left main coronary artery disease by comparing percutaneous coronary angioplasty $(\mathrm{PCl})$ and coronary artery bypass grafting (CABG), we observed a global mortality at three years of approximately $23.86 \%$ in patients treated with $\mathrm{PCl}$ versus $4.54 \%$ in patients treated with CAGB (Hazard Ratio logrank $=7.33,95 \% \mathrm{Cl}$ of ratio 1.999 to 15.19 for $\mathrm{PCl}$, and Hazard Ratio logrank $=0.13,95 \% \mathrm{Cl}$ of ratio 0.06584 to 0.5003 for $C A B G, p=0.0014$ ), as can be seen in figure 4 .

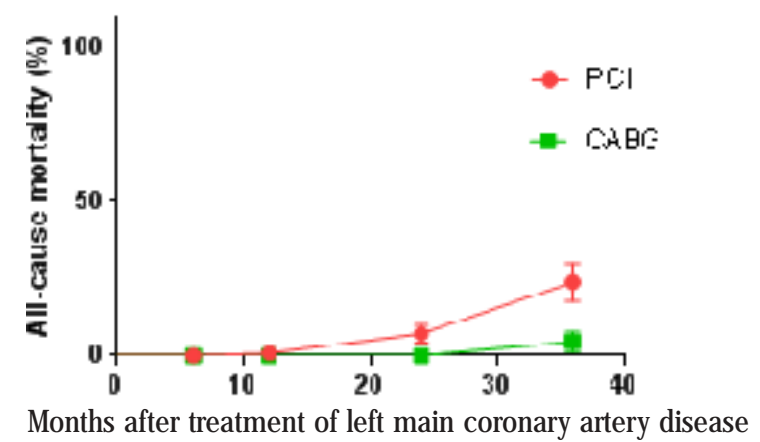

Fig. 4. All-cause mortality (\%) in PCI and CABG Groups after the procedure

Comparing the occurrence of ischemic heart disease symptomatology manifested with angina pectoris, in patients with left main coronary artery disease treated either by percutaneous coronary angioplasty $(\mathrm{PCl})$ or by coronary artery bypass grafting (CABG), we noticed an 
increased rate of recurrence of angina pectoris in patients treated by $\mathrm{PCl}$ (approximately $8.03 \%$ at one year followup, $26.89 \%$ at two years follow-up, and $64.38 \%$ at three years of follow-up), while in patients treated with CABG, the rate of recurrence of angina pectoris was lower ( $0 \%$ at one year follow-up, 3.40\% at two years follow-up, and $40.72 \%$ at three years follow-up) (Hazard Ratio logrank = $2.59,95 \% \mathrm{Cl}$ ratio 2.192 to 5.763 for $\mathrm{PCl}$, and Hazard Ratio logrank $=0.38,95 \% \mathrm{Cl}$ of ratio 0.1735 to 0.4563 for CABG, $p=0.0001)$, as it can be seen in figure 5 .

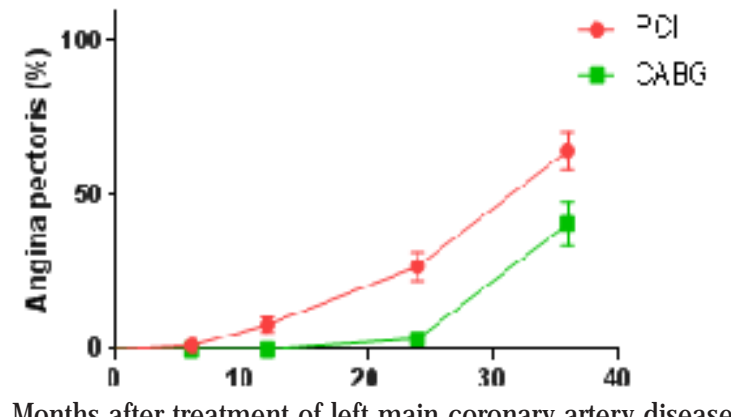

Months after treatment of left main coronary artery disease

Fig. 5. Angina pectoris (\%) in $\mathrm{PCl}$ and $\mathrm{CABG}$ Groups after the procedure

Assessing the occurrence of acute nonfatal myocardial infarction in the two groups of patients (PCl vs. CABG) with $L M C A D$, we observed an increase in the rate of acute nonfatal myocardial infarction in patients with $\mathrm{PCl}(3.41 \%$ at one year follow-up, $12.08 \%$ at two years follow-up, respectively $41.39 \%$ at three years follow-up), much higher than patients who were treated with CABG (who had $0 \%$ at one year follow-up, $1.13 \%$ at two years follow-up, respectively $1.13 \%$ at three years follow-up) with very low rates of acute myocardial infarction (Hazard Ratio logrank $=8.72,95 \% \mathrm{Cl}$ of ratio 3.977 to 19.13 for $\mathrm{PCl}$, and Hazard Ratio logrank $=0.11,95 \% 0.05028$ to 0.2613 for $C A B G, p$ $<0.0001$ ) as it can be seen in figure 6 .

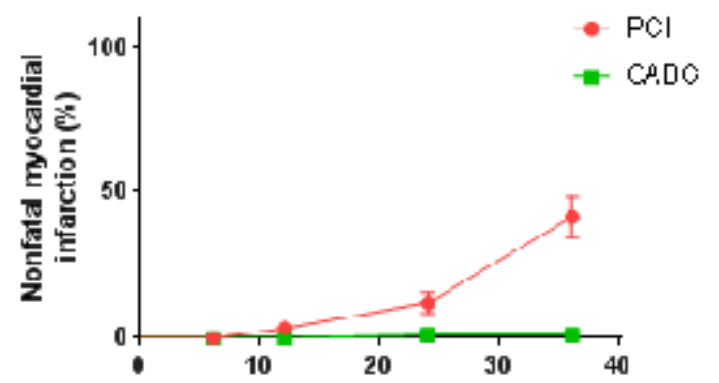

Months after treatment of left main coronary artery disease

Fig. 6. Nonfatal myocardial infarction (\%) in PCl and CABG Groups after the procedure

Regarding the need for revascularization after treatment ( $P C l$ vs CABG) in patients with $L M C A D$, there was a greater need for PCI patients ( $8.03 \%$ for one year follow-up, $24.53 \%$ for two years of follow-up , respectively $61.30 \%$ at three years follow-up) compared to CABG treatment ( $0 \%$ at one year follow-up, $2.27 \%$ at two years follow-up, respectively $28.92 \%$ at three years follow-up) highlighted in fig. 7 (Hazard Ratio logrank $=3.46,95 \% \mathrm{Cl}$ of ratio 2.613 to 7.394 for $\mathrm{PCl}$, and Hazard Ratio logrank $=0.28,95 \% \mathrm{Cl}$ of ratio 0.1352 to 0.3827 for CABG, $p<0.0001$ ).

Assessing the left ventricular ejection fraction (LVEF) for patients with left main coronary artery disease for three years, we noticed a reduction in PCI-treated patients $(7.69 \%$

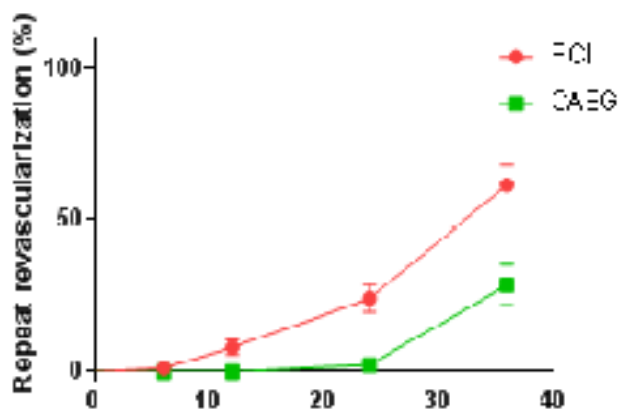

Months after treatment of left main coronary artery disease

Fig. 7. Repeat revascularization (\%) in $\mathrm{PCl}$ and $\mathrm{CABG}$ Groups after the procedure

at one year follow-up, $19.52 \%$ on two years follow-up , respectively $48.41 \%$ at three years follow-up), compared to patients treated with CABG ( $0 \%$ at one year follow-up, $0 \%$ at two years follow-up, $9.09 \%$ at three years followup), there was a decrease in LVEF in a much lower number of patients (Hazard Ratio logrank $=9.30,95 \% \mathrm{Cl}$ of ratio 3.623 to 13.18 for $\mathrm{PCl}$, and Hazard Ratio logrank $=0.14$,

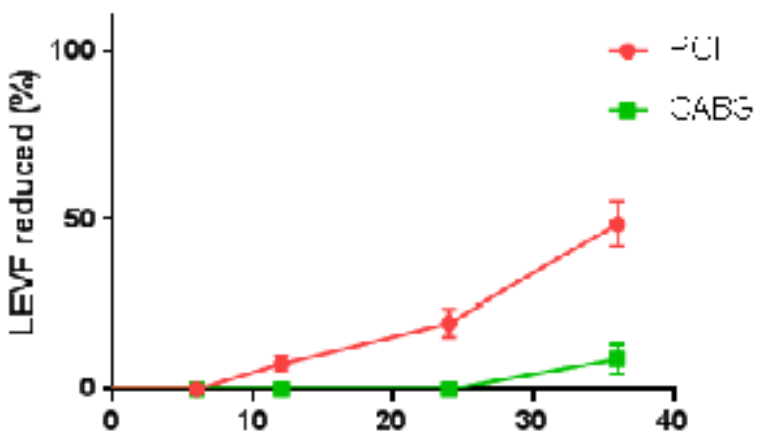

Months after treatment of left main coronary artery disease

Fig. 8. LVEF reduced (\%) in PCl and CABG Groups after the procedure.

$95 \% \mathrm{Cl}$ of ratio 0.07263 to 0.2885 for $\mathrm{CABG}, \mathrm{p}<0.0001$ ) as it can be noticed in figure 8 .

Given these results but also in accordance with the recommendations of the European Society of Cardiology Guidelines for Myocardial Revascularization in 2018 [6], the therapeutic decision on the management of patients with LMCAD should be taken by the heart team [7-28].

The results of our study are compared with the results of the clinical trials conducted most of the time concurrently with the follow-up period of the patients included in our study, results that have been published in the recent years [29-33]. The EXCEL trial compared the treatment of patients with LMCAD either by CABG or by $\mathrm{PCl}$ (using newgeneration DES - EES) and at 3 years follow-up, the primary endpoint of death or stroke occurred with similar frequency in the two groups, but the rate of their occurrence in CABG group was lower than in $\mathrm{PCl}$ group (7.9 vs. $11.5 \%, \mathrm{P}=$ 0.02 ) [26]. Similar results were reported in the NOBLE trials, with a higher rate of major events being recorded in the $\mathrm{PCl}$ group compared to the CABG group (29 vs. $19 \%$, HR $1.48,95 \% \mathrm{Cl} 1.11-1.96, \mathrm{P}=0.007$ ) [1].

\section{Conclusions}

As a final conclusion we can say that the treatment of left main coronary artery disease by using coronary artery bypass grafting is superior to treatment using percutaneous coronary angioplasty. 


\section{References}

1.MAKIKALLIO, T., HOLM, N.R., LINDSAY, M., SPENCE, M.S., ERGLIS, A., MENOWN, I.B., TROVIK, T., ESKOLA, M., ROMPPANEN, H., KELLERTH, T., RAVKILDE, J., JENSEN, L.O., KALINAUSKAS, G., LINDER, R.B., PENTIKAINEN, M., HERVOLD, A., BANNING, A., ZAMAN, A., COTTON, J., ERIKSEN, E., MARGUS, S., SØRENSEN, H.T., NIELSEN, P.H., NIEMELÄ, M., KERVINEN, K., LASSEN, J.F., MAENG, M., OLDROYD, K., BERG, G., WALSH, S.J ., HANRATTY, C.G., KUMSARS, I., STRADINS, P., STEIGEN, T.K., FRÖBERT, O., GRAHAM, A.N., ENDRESEN, P.C., CORBASCIO, M., KAJ ANDER, O., TRIVEDI, U., HARTIKAINEN, J., ANTTILA, V., HILDICK-SMITH, D., THUESEN, L., CHRISTIANSEN, E.H. Percutaneous coronary angioplasty versus coronary artery bypass grafting in treatment of unprotected left main stenosis (NOBLE): a prospective, randomised, open-label, non-inferiority trial. Lancet. 2016 Dec 3;388(10061):2743-2752.

2.GARG, A., RAO, S.V., AGRAWAL, S., THEODOROPOULOS, K., MENNUNI, M., SHARMA, A., GARG, L., FERRANTE, G., MEELU, O.A., SARGSYAN, D., REIMERS, B., COHEN, M., KOSTIS, J.B., STEFANINI, G.G. Meta-Analysis of Randomized Controlled Trials of Percutaneous Coronary Intervention With Drug-Eluting Stents Versus Coronary Artery Bypass Grafting in Left Main Coronary Artery Disease. Am J Cardiol. 2017 J un 15;119(12):1942-1948.

3.KAWECKI, D., MORAWIEC, B., FUDAL, M., MILEJ SKI, W., J ACHE/E, W., NOWALANY-KOZIELSKA, E. Comparison of coronary artery bypass grafting with percutaneous coronary intervention for unprotected left main coronary artery disease. Yonsei Med J. 2012 J an;53(1):58-67.

4.STONE, G.W., MOSES, J.W., LEON, M.B. Left main drug-eluting stents: natural progression or a bridge too far? J Am Coll Cardiol. 2007 Aug 7; 50(6):498-500.

5.COHEN, M.V., GORLIN, R. Main left coronary artery disease. Clinical experience from 1964-1974. Circulation. 1975 Aug; 52(2):27585.

6.NEUMANN, F.J., SOUSA-UVA, M., AHLSSON, A., ALFONSO, F., BANNING, A.P., BENEDETTO, U., BYRNE, R.A., COLLET, J.P., FALK, V., HEAD, S.J ., JUNI, P., KASTRATI, A., KOLLER, A., KRISTENSEN, S.D., NIEBAUER, J., RICHTER, D.J ., SEFEROVIC, P.M., SIBBING, D., STEFANINI, G.G., WINDECKER, S., YADAV, R., ZEMBALA, M.O. 2018 ESC/EACTS Guidelines on myocardial revascularization. Eur Heart J. 2018 Aug 25, p. 0 - 96.

7.FLORESCU, C., ROGOVEANU, I., VERE, C.C., TARTEA, G.C., TARTEA, E.A., MOGOANTA, L. From molecular mechanism to morphological changes in cardiomyopathy. Rom J Morphol Embryol, 2016, 57(4):1207-1214.

8.TARTEA, G.C., FLORESCU, C., PIRICI, D., CARAGEA, D., TARTEA, E.A., VERE, C.C. The substrate of the biopsychosocial influences in the carcinogenesis of the digestive tract. J Mind Med Sci, 2016, 3(2):108-117.

9.DONOIU, I., TARTEA, G.C., CHAVEZ-GONZALEZ, E. Is there a utility for QRS dispersion in clinical practice? J Mind Med Sci, 2017, 4(2):132-141.

10.GHEONEA, I.A., SANDULESCU, S.M., FIRULESCU, S.C., TUDORASCU, D.R., CIOBANU, M.O., BADEA, O., GHEONEA, D.I., SANDULESCU, D.L. A rare case of ovarian splenosis.Rom J MorpholEmbryol. 2016;57(2 Suppl):811-816.

11.CALBOREAN, V., MISCOCI, S. A., ISTRATOAIE, O., GALCEAVA, O., ALEXANDRU, D.O., GUTA, M.M., GHEORMAN, V., PADUREANU, V., FORTOFOIU, C.M., DIJMARESCU, A.L., GHEONEA, D.I., Correlation Between Liver Cirrhosis and Risk of Cardiac Arrhythmias, Rev Chim(Bucharest), 69, no 6, 2018, p. 1527-1532. 12.MESINA, C., STOEAN, L.C., STOEAN, R., SANDITA, V.A., GRUIA, C.L., FOARFA, M.C., ROTARU, L.T., CIOBANU, A.E., MESINA, M., CALBOREAN, V., GHEORMAN, V., CIOBANU, D. Imunohistochemical Expression of CD8, CDX2, P53, D2-40 and K67 in Colorectal Adenocarcinoma, Conventional and Malignant Colo-rectal Polyps.Rev Chim (Bucharest), 69, no.2, 2018, p. 419-428.
13.MIHAILOVICI, A.R., PADUREANU, V., ALBU, C.V., DINESCU V.C., PIRLOG, M.C., DINESCU, S.N., MALIN, R.D., CALBOREAN,V. Myocardial Noncompactation. Rev Chim (Bucharest), 69, no 8, 2018, p. 2209-2012.

14.GHEORMAN, V., MILITARU., CALBOREAN, V., GHEORMAN, L.M., CHIRITA, A.L., MITA, A., GALCEAVA, O., GHEORMAN, V., STANCA, D., UDRISTOIU, I., Clinical and biochemical consideration regarding stress and arrhytmic risk in patients with chronic viral liver diseases, Rev Chim. (Bucharest), 69, no. 4, 2018, p.881-885. 15.GHEORMAN, V., CHIRITA, A.L., DUMITRESCU, E.M., ROGOVEANU, I., ISTRATOAIE, O., GHEORMAN, V., PANA, R.C. Particularities of associating viral hepatitis with pregnancy and mental disorders, Rom J Morphol Embryol 2016, 57(1): 45-50.

16.PUIU, I., DAN, A.O., TARTEA, E.A., ROGOVEANU, O.C., BICA, E.A., DINESCU, S.N., VASILE, R.C., DINESCU, V.C., ROMANESCU, F.M., TUDORASCU, D.R. Assessing Factors that Influence the Level of Glycated Hemoglobin in Children and Adolescents with Type 1 Diabetes, Rev Chim. (Bucharest), 69, no. 11, 2018, p.4233-4236.

17.FLORESCU, C., ISTRATOAIE, O., TARTEA, G.C., PIRICI, D., STREBA, C.T., CATALIN, B., PUIU, I., TARTEA, E.A., CARAGEA, D.C., GHILUSI, M.C., COMANESCU, M.V., ROGOVEANU, I., VERE, C.C. Neuro-neoplastic interrelationships in colorectal level immunohistochemical aspect in three cases and review of the literature. Rom J Morphol Embryol, 2016, 57(2 Suppl):639-650. 18.CIUREA, R.N., ROGOVEANU, I., PIRICI, D., TARTEA, G.C., STREBA, C.T., FLORESCU, C., CATALIN, B., PUIU, I., TARTEA, E.A., VERE, C.C. B2 adrenergic receptors and morphological changes of the enteric nervous system in colorectal adenocarcinoma. World J Gastroenterol, 2017, 23(7):1250-1261.

19.TÂRTEA, E.A., FLORESCU, C., DONOIU, I., PIRICI, D., MIHAILOVICI, A.R., ALBU, V.C., BALAESANU, T.A., IANCAU, M., BADEA, C.D., VERE, C.C., SFREDEL, V. Implications of inflammation and remodeling of the enteric glial cells in colorectal adenocarcinoma. Rom J Morphol Embryol, 2017, 58(2):473-480. 20TUDORASCU, D.R., PIRICI, D., TARTEA, E.A., MUSTAFA, E.R., FLORESCU, C., VERE, C.C., BALEA, A.M., PUIU, I., TÂRTEA, G.C., ALBU, V.C. Synaptophysin expression as prognostic factor for survival in colorectal carcinomas. Rom J Morphol Embryol, 2017, 58(4):1409-1415.

21.CALBOREAN, V., GHEORMAN, V., OCTAVIAN, I., MUSTAFA, R.E., COJ OCARU, P.A., ALEXANDRU, D.O., GALCEAVA, O., MITA, A., $\mathrm{MISCOCI}$, S.A., AL NAMAT, R., GHEONEA, D.I. QT, interval analysis in patients with chronic liver disease, Rev. Chim. (Bucharest), 69 no. 5, 2018, p.1134-1138.

22.MIHAILOVICI, A.R., DELIU, R., MARGARITESCU, C., SIMIONESCU, C.E., DONOIU, I., ISTRATOAIE, O., TUDORASCU, D.R., TARTEA, E.A., GHEONEA, D.I. Collagen I and III, MMP-1 and TIMP-1 immunoexpression in dilated cardiomyopathy, Romanian Journal of Morphology and embryology, 2017, vol.58 (3): 777-781.

23.PUIU, I., STANCU, P., BULUCEA, D., NICULESCU, C., NICOLESCU, V.E., STOIAN, F. Diagnosis of tuberculosis lymphadenitis in children. Pediatrics 2008; 121 (Suppl 2): S130-1.

24.CALBOREAN, V., CIOBANU, D., MIREA, S.C., GALCEAVA, O., GHEORMAN, V., PADUREANU, V., FORTOFOIU, C.M., FORTOFOIU, M., MITA, A., DINESCU, S.N., MISCOCI, S.A., DINESCU, V.C. Benefit of Cardiac Resynchronization Therapy in Patients with Heart Failure. Rev. Chim. (Bucharest), 69, no. 9, 2018, p.2744-2748.

25.PUIU, I., ALBU, C.V., TARTEA, E.A., CALBOREAN, V., GHEORMAN, V., DINESCU, S.N., VASILE, R.C., DINESCU, V.C., BICA, E.C., ROMANESCU, F.M., TUDORASCU, D.R. Relationships Between Glial Enteric Cells, Beta-cell Signaling and Tumor Proliferative Activity in Patients with Colorectal Neoplasia. Rev. Chim. (Bucharest), 69 no. 10, 2018, p.2461-2464.

26.CALBOREAN, V., GHEORMAN, V., DINESCU, N.S., STANCA, D., GALCEAVA,O., FORTOFOIU, M., MITA, A., MIHAILOVICI, A.R., MISCOCI, S.A., BALEANU, V.D., DINESCU,V.C., Arrhythmia risk in patients with chronic hepatic disease. Rev. Chim. (Bucharest), 69, no. 11, 2018, p.3337-3340. 
27.CALBOREAN, V., GHEORMAN, V., CONSTANTIN, C., ISTRATOAIE, 0 . Venous Thromboembolism Secondary to Adult-Onset Still's Disease: a Case Report. Journal of Cardiovascular Emergencies 2018;4(2):101-105.

28.MISCOCl, A., PIRVU, C.D., CALBOREAN, V., STREBA, C.T., ROGOVEANU, O.C., PADUREANU, V., VERE,C.V. The importance of circulating tumor products as liquid biopsies in colorectal cancer. Journal of Mind and Medical Sciences. 2018; 5(1): 39-45

29.STONE, G.W., SABIK, J.F., SERRUYS, P.W., SIMONTON, C.A., GENEREUX, P., PUSKAS, J., KANDZARI, D.E., MORICE, M.C., LEMBO, N., BROWN, W.M. III., TAGGART, D.P., BANNING, A., MERKELY, B., HORKAY, F., BOONSTRA, P.W., VAN BOVEN, A.J., UNGI, I., BOGATS, G., MANSOUR, S., NOISEUX, N., SABATE, M., POMAR, J., HICKEY, M., GERSHLICK, A., BUSZMAN, P., BOCHENEK, A., SCHAMPAERT, E., PAGE, P., DRESSLER, O., KOSMIDOU, I., MEHRAN, R., POCOCK, S.J., KAPPETEIN, A.P.; EXCEL Trial Investigators. Everolimus-eluting stents or bypass surgery for left main coronary artery disease. N Engl J Med 2016; 375:2223-2235. 30.BOUDRIOT, E., THIELE, H., WALTHER, T., LIEBETRAU, C., BOECKSTEGERS, P., POHL, T., REICHART, B., MUDRA, H., BEIER, F., GANSERA, B., NEUMANN, F.J ., GICK, M., ZIETAK, T., DESCH, S., SCHULER, G., MOHR, F.W. Randomized comparison of percutaneous coronary intervention with sirolimus-eluting stents versus coronary artery bypass grafting in unprotected left main stem stenosis. J Am Coll Cardiol 2011; 57:538-545.
31.SERRUYS, P.W., MORICE, M.C., KAPPETEIN, A.P., COLOMBO, A., HOLMES, D.R., MACK, M.J ., STAHLE, E., FELDMAN, T.E., VAN DEN BRAND, M., BASS, E.J., VAN DYCK, N., LEADLEY, K., DAW KINS, K.D., MOHR, F.W.; SYNTAX Investigators S. Percutaneous coronary intervention versus coronary-artery bypass grafting for severe coronary artery disease. N Engl J Med 2009; 360:961-972.

32.PARK, S.J., AHN, J.M., KIM, Y.H., PARK, D.W., YUN, S.C., LEE, J.Y., KANG, S.J., LEE, S.W., LEE, C.W., PARK, S.W., CHOO, S.J ., CHUNG, C.H., LEE, J.W., COHEN, D.J ., YEUNG, A.C., HUR, S.H., SEUNG, K.B., AHN, T.H., KWON, H.M., LIM, D.S., RHA, S.W., JEONG, M.H., LEE, B.K., TRESUKOSOL, D., FU, G.S., ONG, T.K.; BEST Trial Investigators. Trial of everolimus-eluting stents or bypass surgery for coronary disease. N Engl J Med 2015; 372:1204-1212.

33.PARK, S.J., KIM, Y.H., PARK, D.W., YUN, S.C., AHN, J.M., SONG, H.G., LEE, J.Y., KIM, W.J ., KANG, S.J ., LEE, S.W., LEE, C.W., PARK, S.W., CHUNG, C.H., LEE, J.W., LIM, D.S., RHA, S.W., LEE, S.G., GWON, H.C., KIM, H.S., CHAE, I.H., JANG, Y., JEONG, M.H., TAHK, S.J ., SEUNG, K.B. Randomized trial of stents versus bypass surgery for left main coronary artery disease. N Engl J Med 2011; 364:17181727.

$\overline{\text { Manuscript received: } 21.08 .2018}$ 